\title{
Repeated Exposure to Cruciferous Allyl Nitrile Protects against Chemically Induced Skin Inflammation in the Mouse
}

\author{
Hideji Tanii", Tomomi Higashi, Masashi Demura, Kiyofumi Saijoh \\ Department of Hygiene, Graduate School of Medical Science, Kanazawa University, Kanazawa, Japan. \\ Email: *taniih@med.kanazawa-u.ac.jp
}

Received May $17^{\text {th }}, 2012$; revised June $12^{\text {th }}, 2012$; accepted June $19^{\text {th }}, 2012$

\begin{abstract}
Repeated exposure to cruciferous allyl nitrile can induce antioxidant and phase 2 detoxification enzymes in various tissues. In the present study, we examined the effect of five days repeated exposure to allyl nitrile at subtoxic levels $(0$ $400 \mu \mathrm{mol} / \mathrm{kg} / \mathrm{day})$ on the mouse ear. There was an increase in catalase activity in the ear at $100-400 \mu \mathrm{mol} / \mathrm{kg} / \mathrm{day}$, while elevated quinone reductase activity was observed at $400 \mu \mathrm{mol} / \mathrm{kg} /$ day only. Next, after repeated allyl nitrile exposure $(0-400 \mu \mathrm{mol} / \mathrm{kg} /$ day), the skin irritant croton oil was applied to the ear to induce skin acute inflammation (oedema). Compared with the $0 \mu \mathrm{mol} / \mathrm{kg} / \mathrm{day}$ group, animals in the 100 and $400 \mu \mathrm{mol} / \mathrm{kg} /$ day pre-treatment groups showed reduced oedematous response to croton oil. The reduced oedematous response was inversely associated with enhanced myeloperoxidase activity used as index of the presence of neutrophils. These data suggest that repeated exposure to allyl nitrile at subtoxic levels contributes to protection against croton oil-induced ear dermatitis, potentially through decreasing reactive oxygen species and through infiltration of neutrophils.
\end{abstract}

Keywords: Allyl Nitrile; Croton Oil; Catalase; Quinone Reductase; Skin; Inflammation

\section{Introduction}

Cruciferous vegetables are consumed throughout the world. Food preparation and eating cause release of the plant enzyme myrosinase, which causes hydrolysis of glucosinolates into numerous breakdown products including nitriles, isothiocyanates, and indoles [1-3]. Hydrolysis of the glucosinolate sinigrin leads to formation of allyl nitrile and allyl isothiocyanate in fermented cabbage $[4,5]$. We reported similar breakdown products following incubation of cabbage homogenates in water or in buffer at $\mathrm{pH} 1.0$ [6], and following in vitro digestion of sinigrin by Bifidobacteria sp. [7]. Thus, allyl nitrile absorbed by the body may have relevance to human health.

Rodent studies have demonstrated that exposure to high levels of allyl nitrile induces behavioural abnormalities [8,9], apoptosis in the brain [9], and alterations in the $\gamma$-aminobutyric acid system [10]. Allyl nitrile exposure can also cause vestibular and auditory hair cell degeneration, corneal opacity, and gliosis in the retina and olfactory bulbs [11]. At subtoxic levels, repeated exposure to allyl nitrile increases antioxidant and phase 2 detoxification enzymes in mice [12-14]. In those studies,

"Corresponding author. quinone reductase $(\mathrm{QR})$ was up-regulated in the stomach, small intestine, urinary bladder, kidneys, lungs and brain, glutathione peroxidase was upregulated in the kidneys and small intestine, thioredoxin reductase was upregulated in the liver, kidneys and rectum, glutathione Stransferase (GST) was upregulated in the stomach, rectum, kidneys, lungs and brain, and glutathione was upregulated in the stomach, rectum, urinary bladder and brain. The increased expression of antioxidant and phase 2 enzymes are of particular interest to epidemiological studies indicating an inverse association between crucifer intake and the incidence of various cancers [15-19].

The skin is a major site of defence against pathogenic agents and is exposed to many pro-inflammatory environmental agents. The potential for skin irritation or skin sensitization from workplace chemicals is a great concern for individuals. However, it remains unknown whether repeated exposure to this allyl nitrile can upregulate antioxidant and phase 2 enzymes in the skin to suppress inflammation produced by environmental agents.

In the present study, we examined the effect of five days repeated allyl nitrile exposure at subtoxic levels on the mouse ear skin by measuring the activities of catalase, glutathione peroxidase, QR, and GST. Furthermore, we 
evaluated anti-inflammatory effect of allyl nitrile exposure by measuring oedematous response and leukocyte infiltration following inflammation induction using the croton oil-induced mouse ear dermatitis, a model of skin acute inflammation [20].

\section{Materials and Methods}

\subsection{Materials}

Nicotinamide adenine dinucleotide phosphate (NADPH), 2,6-dichloroindophenol and dicumarol were purchased from Sigma-Aldrich Ltd. (St. Louis, MO, USA), croton oil, hexadecyltrimethylammonium bromide (HTAB) and allyl nitrile (3-butenenitrile, CAS No. 109-75-1, purity > 98\%) from Tokyo Kasei Organic Chemicals (Tokyo, Japan), rabbit anti-myeloperoxidase polyclonal antibody (Ab-1) from Thermo Fischer Scientific (Fremont, CA, USA), Vectastain ABC kit (peroxidase rabbit IgG) from Vector Laboratories (Burlingame, CA, USA), and sodium pentobarbital from Dainihon Seiyaku Co. (Tokyo, Japan). All other chemicals were purchased from Nacalai Tesque (Kyoto, Japan).

\subsection{Animals and Treatments}

All animal experiments were performed according to the Guidelines of the Committee on Animal Experimentation of Kanazawa University. Male ddY mice weighing 26 $30 \mathrm{~g}$ obtained from Japan SLC Co. (Shizuoka, Japan) were used. Animals were maintained at $22^{\circ} \mathrm{C} \pm 2{ }^{\circ} \mathrm{C}$ under a 12:12 h light/dark cycle and allowed free access to tap water and laboratory food (CRF-1; Charles River Japan Inc., Yokohama, Japan).

Groups of 3 - 4 animals were administered allyl nitrile at subtoxic levels $(100,200$, or $400 \mu \mathrm{mol} / \mathrm{kg})$ or vehicledistilled water (control; $4 \mathrm{~mL} / \mathrm{kg}$ ) daily for five days by gastric intubation, based on our previous findings [13]. For antioxidant and phase 2 enzyme analyses, the animals were sacrificed on the sixth day. For induction of dermatitis, the animals were given croton oil on the sixth day as described in Section 2.4.

\subsection{Tissue Preparation and Biochemical Assays}

Mice were anesthetized with $100 \mathrm{mg} / \mathrm{kg}$ sodium pentobarbital and perfused transcardially with $1.15 \% \mathrm{KCl}$. An ear plug was immediately taken and stored at $-80^{\circ} \mathrm{C}$ until analysis. Cytosolic supernatant for enzyme analyses was prepared as previously described [12]. Protein concentrations were measured according to the method of Bradford [21] using bovine serum albumin as the standard. QR activity was measured according to the spectrophotometric method of Ernster [22], and GST activity according to the spectrophotometric method of Habig et al.
[23] using 1-chloro-2,4-dinitrobenzene as the substrate. Catalase activity was measured using the method of Abei [24] using $\mathrm{H}_{2} \mathrm{O}_{2}$ as the substrate, and glutathione peroxidase activity was measured according to the spectrophotometric method of Paglia and Valentine [25] using $\mathrm{H}_{2} \mathrm{O}_{2}$ as the substrate and NADPH as the source of reducing equivalents.

\subsection{Croton Oil-Induced Dermatitis}

Skin acute inflammation was induced on the right ear by application of $40 \mu \mathrm{g}$ of croton oil dissolved in $15 \mu \mathrm{L}$ of acetone, while $15 \mu \mathrm{L}$ of acetone was applied on the left ear. At selected times following the croton oil application, animals were sacrificed and a $63.3 \mathrm{~mm}^{2}$ tissue punch was taken from both the right and left ears to evaluate oedema and the leukocyte infiltrate. Quantitative assessment of oedema was performed by measuring the difference in weight between the portions taken from the right and left ears. The effect of repeated exposure to allyl nitrile on oedema development was quantified up to $48 \mathrm{~h}$ following croton oil application.

\subsection{Assessment of Neutrophilic Granulocyte Infiltrate}

Quantitative assessment of the cellular infiltrate was performed by measuring myeloperoxidase activity, an index of the presence of neutrophilic granulocytes [20]. Myeloperoxidase was extracted by HTAB according to Bradley et al. [26]. A portion of ear $\left(63.6 \mathrm{~mm}^{2}\right)$ was suspended in $1 \mathrm{~mL}$ of $0.1 \mathrm{M}$ phosphate buffer $\mathrm{pH} 6.0$, containing $0.1 \% \mathrm{HTAB}$, and then homogenized by Polytron (Kinematica GmbH, Switzerland) for 1 min setting at 9. The homogenates were centrifuged at $15,000 \mathrm{~g}$ at $4^{\circ} \mathrm{C}$ for $20 \mathrm{~min}$, and the resulting supernatant was used for the enzymatic assay. Myeloperoxidase activity was measured according to the method of Maehly and Chance [27] with guaiacol as the substrate, and was expressed as $\mu \mathrm{mol}$ of guaiacol oxidized $/ \mathrm{min} / 1 \mathrm{~mL}$ of supernatant.

\subsection{Immunohistochemistry}

Ear biopsies, fixed in $4 \%$ paraformaldehyde followed by in $30 \%$ sucrose, were sectioned by cryostat $(16 \mu \mathrm{m}$, performed as previously described [10]. Tissue sections were incubated with primary antibody (rabbit anti-myeloperoxidase, 1:800) for four days at $4^{\circ} \mathrm{C}$. Sections were then incubated in Tris- $\mathrm{HCl}$ buffered saline $(\mathrm{pH}$ 7.4) containing $0.04 \%$ diaminobenzidine, $0.08 \%$ nickel ammonium sulfate, and $0.003 \% \mathrm{H}_{2} \mathrm{O}_{2}$ for $10 \mathrm{~min}$ for visualizetion.

\subsection{Statistics}

Statistical analyses were performed by analysis of vari- 
ance followed by the Dunnett's test for multiple comparisons. The level of significance was set at $\mathrm{P}<0.05$.

\section{Results}

\subsection{Induction of Antioxidant and Phase 2 Detoxification Enzymes in the Ear}

Exposure to five days repeated allyl nitrile at 100, 200, and $400 \mu \mathrm{mol} / \mathrm{kg}$ /day levels resulted in an increase in catalase activities in the ear $(\mathrm{P}<0.05)$ (Figure 1(a)). Allyl nitrile at 100 and $200 \mu \mathrm{mol} / \mathrm{kg} /$ day had no effect on QR activity, while QR activity was elevated at $400 \mu \mathrm{mol} /$ $\mathrm{kg} /$ day $(\mathrm{P}<0.05)$ (Figure 1(b)). The activities of GST and glutathione peroxidase in the ear were too low to measure at any dose of allyl nitrile ( 0 - $400 \mu \mathrm{mol} / \mathrm{kg} / \mathrm{day})$.

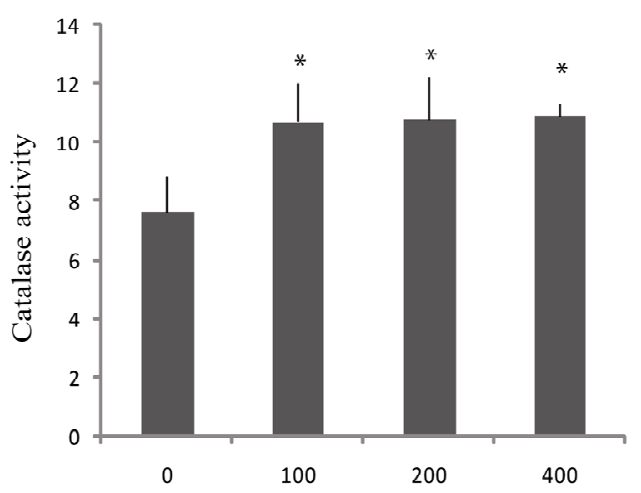

Treatment with allyl nitrile ( $\mu \mathrm{mol} / \mathrm{kg} / \mathrm{day})$

(a)

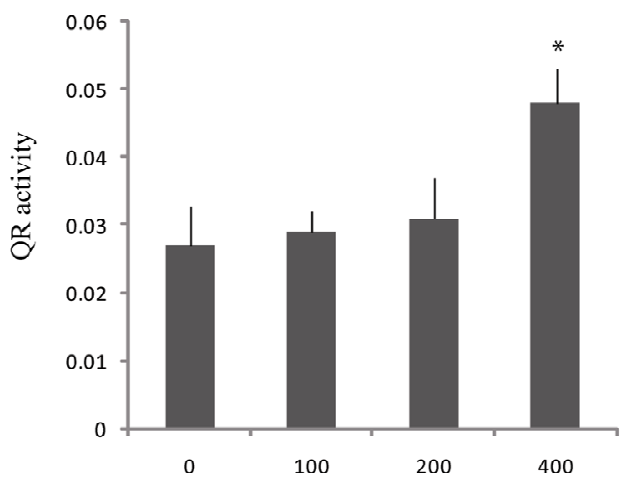

Treatment with allyl nitrile ( $\mu \mathrm{mol} / \mathrm{kg} /$ day)

(b)

Figure 1. Catalase and quinone reductase $(Q R)$ activities in the ear following repeated allyl nitrile exposure. Mice were administered oral allyl nitrile at $0,100,200$, or $400 \mu \mathrm{mol} / \mathrm{kg}$ for five days. On the sixth day, catalase (a) and QR (b) activities were assessed. Catalase activity was defined as $\mu \mathrm{mol}$ of $\mathrm{H}_{2} \mathrm{O}_{2}$ consumed $/ \mathrm{min} / \mathrm{mg}$ of protein, and $\mathrm{QR}$ activity as $\mu \mathrm{mol}$ of 2,6-dichloroindophenol $\mathrm{reduced} / \mathrm{min} / \mathrm{mg}$ of $\mathrm{pro}$ tein. Values represent mean \pm SD of three animals. Values with asterisk are significantly different $(P<0.05)$ from the control ( $0 \mu \mathrm{mol}$ allyl nitrile/kg/day).

\subsection{Effect of Allyl Nitrile on Oedematous Response following Croton Oil-Induced Dermatitis}

Control animals at $0 \mu \mathrm{mol} / \mathrm{kg} /$ day showed oedema after croton oil application, peaking at $6 \mathrm{~h}$ post-dosing, and then decreasing 24 and $48 \mathrm{~h}$ post-dosing (Figure 2). There was a significant reduction in oedema at $24 \mathrm{~h}$ post-dosing in the $100 \mu \mathrm{mol} / \mathrm{kg} /$ day allyl nitrile group (P $<0.05)$, and at 6 and $24 \mathrm{~h}$ post-dosing in the $400 \mu \mathrm{mol} /$ $\mathrm{kg} /$ day group $(\mathrm{P}<0.05)$. There was no effect of 200 $\mu \mathrm{mol} / \mathrm{kg} /$ day allyl nitrile on oedema throughout the observation period.

\subsection{Myeloperoxidase Activity after Croton Oil Application}

The recruitment of leukocytes in the inflamed ear tissue was measured as myeloperoxidase activity. In control animals exposed to $0 \mu \mathrm{mol} / \mathrm{kg} /$ day allyl nitrile, myeloperoxidase activity appeared at $6 \mathrm{~h}$ post-dosing with croton oil, reached a peak at $24 \mathrm{~h}$, and decreased at $48 \mathrm{~h}$ (Figure 3). There was a significant increase in myeloperoxidase activity at $24 \mathrm{~h}$ post-dosing in the $100 \mu \mathrm{mol} /$ $\mathrm{kg}$ /day allyl nitrile group $(\mathrm{P}<0.05)$, and at $6 \mathrm{~h}$ postdosing in the $400 \mu \mathrm{mol} / \mathrm{kg} / \mathrm{day}(\mathrm{P}<0.05)$, while there was no effect in the $200 \mu \mathrm{mol} / \mathrm{kg} /$ day group.

\subsection{Myeloperoxidase Immunostaining in the Ear}

Immunostaining with antimyeloperoxidase revealed evidence of tissue oedema and leukocyte infiltration after

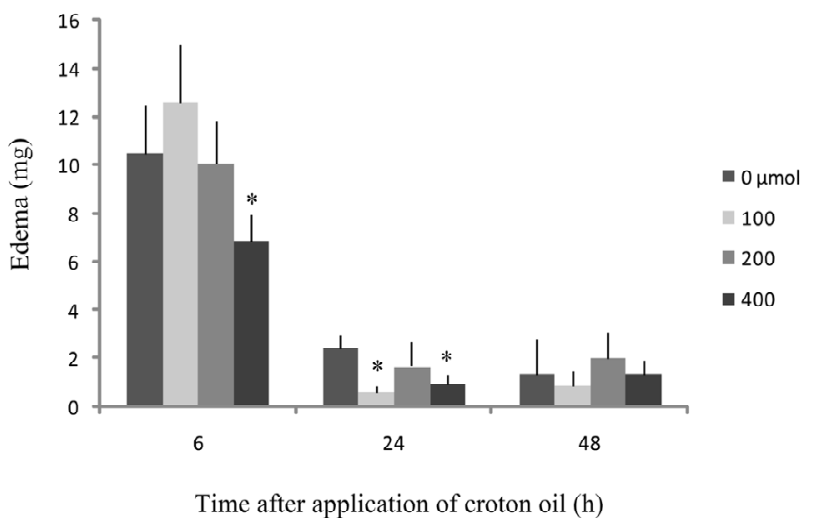

Figure 2. Oedematous response to croton oil application in

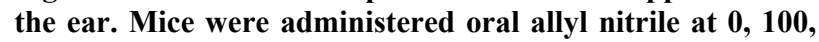
200 , or $400 \mu \mathrm{mol} / \mathrm{kg}$ for five days. On the sixth day, croton oil was applied on the right ear, and acetone on the left ear. Oedema (difference in weight between $63.6 \mathrm{~mm}^{2}$ punches from the treated and untreated ears) was assessed up to 48 $h$ following croton oil application. Values represent mean \pm SD of four animals. Values with asterisk within hours after the application are significantly different $(P<0.05)$ from the control $(0 \mu \mathrm{mol}$ allyl nitrile/kg/day). 


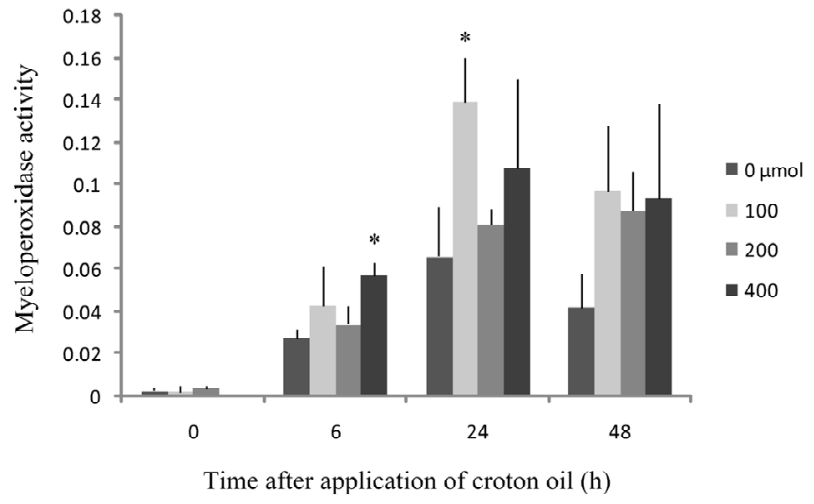

Figure 3. Myeloperoxidase activity in the ear after croton oil application. Mice were administered oral allyl nitrile at 0 , 100,200 , or $400 \mu \mathrm{mol} / \mathrm{kg}$ for five days. On the sixth day, croton oil was applied to the right ear. Myeloperoxidase activity ( $\mu \mathrm{mol}$ of guaiacol oxidized $/ \mathrm{min} / 63.6 \mathrm{~mm}^{2}$ tissue) in the right ear was assessed up to $48 \mathrm{~h}$ following croton oil application. Values represent mean \pm SD of four animals. Values with asterisk within hours after the application are significantly different $(P<0.05)$ from the control $(0 \mu \mathrm{mol}$ allyl nitrile/kg/day).

croton oil application. The ear from animals pre-treated with $0 \mu \mathrm{mol} / \mathrm{kg}$ allyl nitrile for five days showed the oe 0 dematous response and leukocyte infiltration at $6 \mathrm{~h}$ post-dosing with croton oil (Figure 4(A)), while there was no response at $6 \mathrm{~h}$ after acetone only application (Figure 4(E)). At 24 post-dosing the oedema had recovered while leukocyte infiltration was still evident (Figure 4(B)). The ear from the $400 \mu \mathrm{mol} / \mathrm{kg} /$ day group also displayed the oedematous response and leukocyte infiltration at $6 \mathrm{~h}$ post-dosing with croton oil (Figure 4(C)), while at $24 \mathrm{~h}$ the oedema had recovered and there was evidence of myeloperoxidase-positive cells (Figure 4(D)).

\section{Discussion}

The present study showed that repeated exposure to allyl nitrile induced antioxidant and phase 2 enzymes in the skin, which resulted in reduced oedema and increased neutrophils (enhanced myeloperoxidase activity) after croton oil application. The induction of catalase and QR in the skin following repeated exposure to cruciferous allyl nitrile is consistent with previous reports showing a similar induction of antioxidant and phase 2 enzymes in other tissues [12-14]. These data suggest that allyl nitrile exposure is protective against chemically induced inflammation.

We employed the croton oil-induced ear oedema for a model of skin acute inflammation. Croton oil contains phorbol myristate acetate, which triggers keratinocytes in the skin to produce soluble mediators important in contact irritancy including interleukin- $1 \alpha$, interleukin- 8 , tumour necrosis factor- $\alpha$, and granulocyte/macrophage
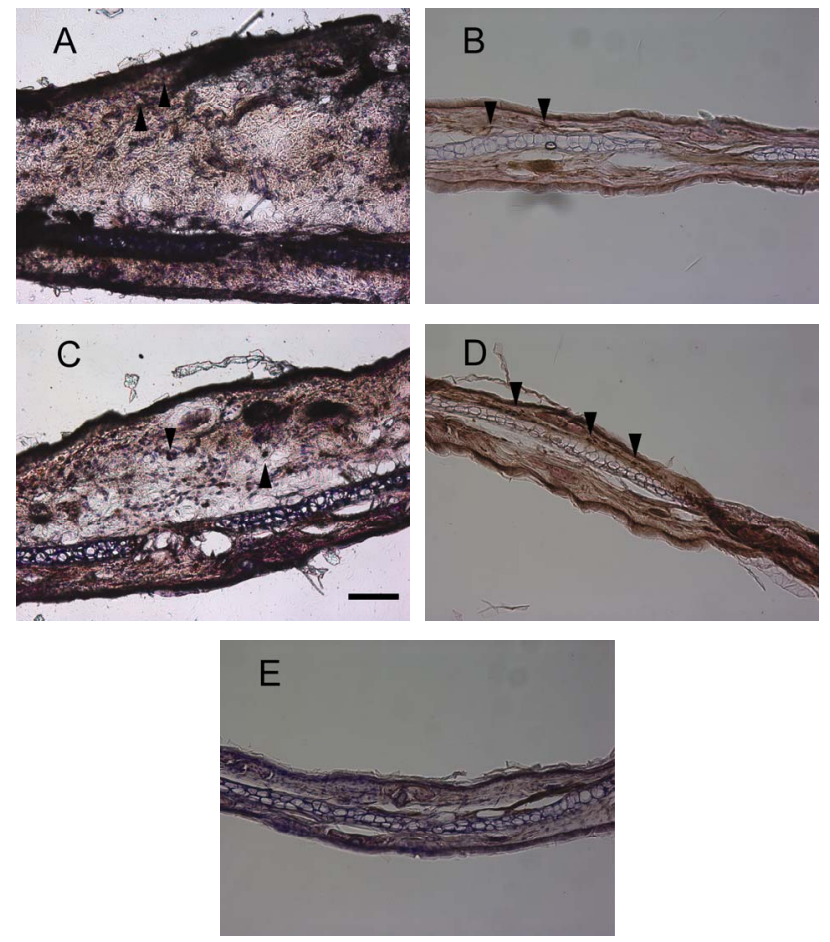

Figure 4. Mouse ear after the induction of the croton oil dermatitis. Mice were administered oral allyl nitrile at 0 (A), (B), and (E) or 400 (C) and (D) $\mu \mathrm{mol} / \mathrm{kg}$ for five days. On the sixth day, croton oil (A), (B), (C), and (D) or acetone alone $(\mathrm{E})$ was applied to the right or left ears, respectively. At $6 \mathrm{~h} \mathrm{(A),} \mathrm{(C),} \mathrm{and} \mathrm{(E)} \mathrm{and} 24 \mathrm{~h}$ (B) and (D) after croton oil application, immunostaining of infiltrated leukocytes with antimyeloperoxidase antibody was performed. Arrowheads indicate representative positive immunostained cells. Scale bar: $100 \mu \mathrm{m}$.

colony stimulating factor [28]. Phorbol myristate acetate also activates protein kinase $\mathrm{C}$, resulting in activation of the reactive oxygen species-generating NADPH-dependent oxidase in polymorphonuclear neutrophils [29]. These reactive oxygen species can exaggerate contact irritancy. Catalase and QR induced by allyl nitrile exposure can decrease the reactive oxygen species formed in neutrophils, which may contribute to the reduced oedema observed with allyl nitrile treatment in response to croton oil exposure. Interestingly, there is growing evidence for a role of nuclear factor-erythroid 2-related factor-2 (Nrf2) in inflammatory disorders [30]. Nrf2 is a transcription factor that plays an important role in cellular defence against oxidative insults by inducing antioxidant and phase 2 detoxification enzymes, and has been suggested to have a protective role in inflammation-mediated disorders.

Myeloperoxidase activity was used as index of the presence of neutrophils in this study. Neutrophils are known to play an important role in resistance against extracellular pathogens and in acute inflammation, and 
act as phagocytic cells, releasing lytic enzymes and producing reactive oxygen species [31]. Additionally, recent evidence suggests that neutrophils can reduce inflammation through the production of anti-inflammatory molecules [32]. In this study, the degree of oedema was inversely associated with myeloperoxidase activity, suggesting that that increased neutrophils (enhanced myeloperoxidase) may have contributed to resolution of inflammation. Nevertheless, it is unclear why allyl nitrile exposure increased neutrophils recruitment after croton oil application, although repeated exposure to the breakdown product allyl isothiocyanate, an Nrf2 activator, was reported to induce neutrophil recruitment in blood from rats $[33,34]$.

In conclusion, repeated exposure to allyl nitrile at subtoxic levels can induce catalase and QR in the skin of the ear. Further, this pre-treatment was protective against the oedematous response to the irritant croton oil, likely via a reduction in reactive oxygen species and through infiltration of neutrophils.

\section{REFERENCES}

[1] J. W. Fahey, A. T. Zelcmann and P. Talalay, "The Chemical Diversity and Distribution of Glucosinolates and Isothiocyanates among Plants," Phytochemistry, Vol. 56, No. 1, 2001, pp. 5-51. doi:10.1016/S0031-9422(00)00316-2

[2] G. R. Fenwick, R. K. Heaney and W. J. Mullin, "Glucosinolates and Their Breakdown Products in Food and Food Plants," CRC Critical Reviews in Food Science and Nutrition, Vol.18, No. 2, 1983, pp. 123-201. doi:10.1080/10408398209527361

[3] J. W. Lampe and S. Peterson, "Brassica, Biotransformation and Cancer Risk: Genetic Polymorphism Alter the Preventive Effects of Cruciferous Vegetables," The Journal of Nutrition, Vol. 132, No. 10, 2002, pp. 2991-2994.

[4] M. Tolonen, M. Taipale, B. Viander, J. M. Pihlava, H. Korhoren and E. L. Ryhanen, "Plant-Derived Biomolecules in Fermented Cabbage," Journal of Agricultural and Food Chemistry, Vol. 50, No. 23, 2002, pp. 6798-6803. doi:10.1021/if0109017

[5] L. G. West, A. F. Brandenhop and J. L. McLaughlin, "Allyl Isothiocyanate and Allyl Cyanide Production in Cell-Free Cabbage Leaf Extracts, Shredded Cabbage, and Cole Slaw," Journal of Agricultural and Food Chemistry, Vol. 25, No. 6, 1977, pp. 1234-1238. doi:10.1021/if60214a043

[6] H. Tanii, T. Takayasu, T. Higashi, S. Leng and K. Saijoh, "Allylnitrile: Generation from Cruciferous Vegetables and Behavioral Effects on Mice of Repeated Exposure," Food and Chemical Toxicology, Vol. 42, No. 3, 2004, pp. 453-458. doi:10.1016/j.fct.2003.10.007

[7] D. L. Cheng, K. Hashimoto and Y. Uda, "In Vitro Digestion of Sinigrin and Glucotropaeolin by Single Strains of Bifidobacterium and Identification of the Digestive Prod- ucts," Food and Chemical Toxicology, Vol. 42, No. 3, 2004, pp. 351-357. doi:10.1016/i.fct.2003.09.008

[8] H. Tanii, Y. Kurosaka, M. Hayashi and K. Hashimoto, "Allylnitrile: A Compound Which Induces Long-Term Dyskinesia in Mice Following a Single Administration," Experimental Neurology, Vol. 103, No. 1, 1989, pp. 6467. doi:10.1016/0014-4886(89)90186-6

[9] X. P. Zang, H. Tanii, K. Kobayashi, T. Higashi, R. Oka, Y. Koshino and K. Saijoh, "Behavioral Abnormalities and Apoptotic Changes in Neurons in Mice Brain following a Single Administration of Allylnitrile," Archives of Toxicology, Vol. 73, No. 1, 1999, pp. 22-32. doi:10.1007/s002040050582

[10] H. Tanii, X. P. Zang, N. Saito and K. Saijoh, "Involvement of GABA Neurons in Allylnitrile-Induced Dyskinesia," Brain Research, Vol. 887, No. 2, 2000, pp. 454-459. doi:10.1016/S0006-8993(00)03035-3

[11] E. Balbuena and J. Llorens, "Behavioural Disturbances and Sensory Pathology Following Allylnitrile Exposure in Rats," Brain Research, Vol. 904, No. 2, 2001, pp. 298306. doi:10.1016/S0006-8993(01)02476-3

[12] H. Tanii, T. Higashi, F. Nishimura, Y. Higuchi and K. Saijoh, "Induction of Detoxication Enzymes in Mice by Naturally Occurring Allyl Nitrile," Journal of Agricultural and Food Chemistry, Vol. 53, No. 23, 2005, pp. 8993-8996. doi:10.1021/if0516282

[13] H. Tanii, T. Higashi, F. Nishimura, Y. Higuchi and K. Saijoh, "Effects of Cruciferous Allyl Nitrile on Phase 2 Antioxidant and Detoxification Enzymes," Medical Science Monitor, Vol. 14, No. 10, 2008, pp. BR189-BR192.

[14] H. Tanii, T. Higashi and K. Saijoh, "Preconditioning with Subneurotoxic Allyl Nitrile: Protection against Allyl Nitrile Neurotoxicity," Food and Chemical Toxicology, Vol. 48, No. 2, 2010, pp. 750-754. doi:10.1016/i.fct.2009.12.010

[15] S. Graham, H. Dayal, M. Swanson, A. Mittelman and G. Wilkinson, "Diet in the Epidemiology of Cancer of the Colon and Rectum," Journal of the National Cancer Institute, Vol. 61, No. 3, 1978, pp. 709-714.

[16] W. Haenszel, F. B. Locke and M. Segi, "A Case-Control Study of Large Bowel Cancer in Japan," Journal of the National Cancer Institute, Vol. 64, No. 1, 1980, pp. 17-22.

[17] T. K. Lam, L. Gallicchio, K. Lindsley, M. Shiels, E. Hammond, X. Tao, L. Chen, K. A. Robinson, L. E. Caulfield, J. G. Herman, E. Guallar and A. J. Alberg, "Cruciferous Vegetable Consumption and Lung Cancer Risk: A Systematic Review," Cancer Epidemiology Biomarkers \& Prevention, Vol. 18, No. 1, 2009, pp. 184-195. doi:10.1158/1055-9965.EPI-08-0710

[18] L. Tang, G. R. Zirpoli, K. Guru, K. B. Moysich, Y. Zhang, C. B. Ambrosone and S. E. McCann, "Consumption of Raw Cruciferous Vegetables Is Inversely Associated with Bladder Cancer Risk," Cancer Epidemiology Biomarkers \& Prevention, Vol. 17, No. 4, 2008, pp. 938-944. doi:10.1158/1055-9965.EPI-07-2502

[19] D. T. Verhoeven, R. A. Goldbohm, G. van Poppel, H. Verhagan and P. A. van den Brandt, "Epidemiological 
Studies on Brassica Vegetables and Cancer Risk," Cancer Epidemiology Biomarkers \& Prevention, Vol. 5, No. 9, 1996, pp. 733-748.

[20] A. Tubaro, P. Dri, G. Delbello, C. Zilli and R. Della Loggia, "The Croton Oil Ear Test Revisited," Agents and Actions, Vol. 17, No. 3-4, 1985, pp. 347-349. doi:10.1007/BF01982641

[21] M. M. Bradford, "A Rapid and Sensitive Method for the Quantitation of Microgram Quantities of Protein Utilizing the Principle of Protein-Dye Binding," Analytical Biochemistry, Vol. 72, No. 1-2, 1976, pp. 248-254. doi:10.1016/0003-2697(76)90527-3

[22] L. Ernster, "DT Diaphorase," Methods in Enzymology, Vol. 10, 1967, pp. 309-317. doi:10.1016/0076-6879(67)10059-1

[23] W. H. Habig, M. J. Pabst and W. B. Jakoby, "Glutathione S-Transferases. The First Enzymatic Step in Mercapturic Acid Formation," The Journal of Biological Chemistry, Vol. 249, No. 22, 1974, pp. 7130-7139.

[24] H. Abei, "Catalase in Vitro," Methods in Enzymology, Vol. 105, 1984, pp. 121-126. doi:10.1016/S0076-6879(84)05016-3

[25] D. Paglia and W. Valentine, "Studies on the Quantitative and Qualitative Characterization of Erythrocyte Glutathione Peroxidase," Journal of Laboratory and Clinical Medicine, Vol. 70, No. 1, 1967, pp. 158-169.

[26] P. P. Bradley, D. A. Priebat, R. D. Christensen and G. Rothstein, "Measurement of Cutaneous Inflammation: Estimation of Neutrophil Content with an Enzyme Marker," Journal of Investigative Dermatology, Vol. 78, No. 3, 1982, pp. 206-209. doi:10.1111/1523-1747.ep12506462

[27] A. C. Maehly and B. Chance, "The Assay of Catalases and Peroxidases," Methods of Biochemical Analysis, Vol. 1, 1954, pp. 357-424. doi:10.1002/9780470110171.ch14

[28] J. L. Wilmer, F. G. Burleson, F. Kayama, J. Kanno and M.
I. Luster, "Cytokine Induction in Human Epidermal Keratinocytes Exposed to Contact Irritants and Its Relation to Chemical-Induced Inflammation in Mouse Skin," Journal of Investigative Dermatology, Vol. 102, No. 6, 1994, pp. 915-922. doi:10.1111/1523-1747.ep12383512

[29] W. M. Nauseef, B. D. Volpp, S. McCormick, K. G. Leidal and R. A. Clark, "Assembly of the Neutrophil Respiratory Burst Oxidase. Protein Kinase C Promotes Cytoskeletal and Membrane Association of Cytosolic Oxidase Components," The Journal of Biological Chemistry, Vol. 266, No. 9, 1991, pp. 5911-5917.

[30] J. Kim, Y.-N. Cha and Y.-J. Surh, "A Protective Role of Nuclear Factor-Erythroid 2-Related Factor-2 (Nrf2) in Inflammatory Disorders," Mutation Research/Fundamental and Molecular Mechanisms of Mutagenesis, Vol. 690, No. 1-2, 2010, pp. 12-23. doi:10.1016/j.mrfmmm.2009.09.007

[31] C. Nathan, "Neutrophils and Immunity: Challenges and Opportunities," Nature Reviews Immunology, Vol. 6, No. 3, 2006, pp. 173-182. doi:10.1038/nri1785

[32] A. Mantovani, M. A. Cassatella, C. Costantini and S. Jaillon, "Neutrophils in the Activation and Regulation of Innate and Adaptive Immunity," Nature Reviews Immunology, Vol. 11, No. 8, 2011, pp. 519-531. doi:10.1038/nri3024

[33] K. Imaizumi, S. Sato, Y. Sakakibara, S. Mori, M. Ohkuma, Y. Kawashima, T. Ban, H. Sasaki and K. Tachiyashiki, "Allyl Isothiocyanate-Induced Changes in the Distribution of White Blood Cells in Rats," The Journal of Toxicological Sciences, Vol. 35, No. 4, 2010, pp. 583-589. doi: $10.2131 /$ jts. 35.583

[34] R. Munday and C. M. Munday, "Selective Induction of Phase II Enzymes in the Urinary Bladder of Rats by Allyl Isothiocyanate, a Compound Derived from Brassica Vegetables," Nutrition and Cancer, Vol. 44, No. 1, 2002, pp. 52-59. doi:10.1207/S15327914NC441 7. 